Sains Malaysiana 49(10)(2020): 2599-2608

http://dx.doi.org/10.17576/jsm-2020-4910-25

\title{
Experimental and Numerical Investigation of Fluid Flow and Heat Transfer in Circular Micro-Channel
}

\author{
(Penyelidikan Uji Kaji dan Berangka bagi Aliran Bendalir dan Pemindahan Haba dalam Mikro-Saluran Membulat)
}

\author{
AbdulmajeEd AlmaneEA*
}

\begin{abstract}
Nowadays, there is a large demand for many electronic devices such as the laptop, and cell phone. The heat generated by such electronic component increases due to continuous functioning. Implementing microchannel could be a good solution despite the heat from microminiature refrigerators, microelectronics, micro heat pipe spreader, fuel processing biomedical, and aerospace. Therefore, several investigations have been done to improve the performance of such continuous operating electronic devices by dissipating heat with the use of microchannels. In this study, an experimental and numerical investigation is done for the circular microchannel having the hydraulic diameter of $253 \mu \mathrm{m}$ and 63 $\mathrm{mm}$ in length under the condition of constant wall temperature by submerging the microchannels in the oil at constant temperature and water is forced to pass through total 5 microchannels. Experimental conducted for various flow rates shows that the microchannel has a significant impact on the heat transfer rate for the considered flow rate. Numerical results through COMSOL 5.1 software show good agreement with the experimental results. It is observed that the heat transfer coefficient increases with the Reynolds number whereas friction factor decreases with Reynolds number. Based on numerical and experimental results, empirical correlations for friction factor and Nusselt number are suggested to provides a reasonable estimate of heat transfer in the microchannel.
\end{abstract}

Keywords: Friction factor; heat transfer; microchannels; Nusselt number; Reynolds number

\section{ABSTRAK}

Pada masa ini terdapat banyak permintaan barang peranti elektronik seperti komputer riba dan telefon bimbit. Haba yang dihasilkan oleh komponen elektronik akan meningkat dengan penggunaan secara berterusan. Penggunaan mikrosaluran boleh menjadi penyelesaian yang baik di sebalik haba yang terhasil daripada peti sejuk mikro, mikroelektronik, penyebar paip haba mikro, bioperubatan pemprosesan bahan bakar dan aeroangkasa. Oleh itu, beberapa penyelidikan telah dilakukan untuk meningkatkan prestasi peranti elektronik yang beroperasi secara berterusan melalui pembuangan haba dengan penggunaan mikrosaluran. Dalam kajian ini, penyelidikan secara uji kaji dan berangka telah dijalankan untuk mikrosaluran bulat yang berdiameter 253 um dan panjang $63 \mathrm{~mm}$ di bawah keadaan suhu dinding tetap dengan merendam mikrosaluran dalam minyak pada suhu tetap dan air dipaksa melalui keseluruhan 5 mikrosaluran secara keseluruhan. Uji kaji dijalankan dalam kadar aliran yang berbeza dan ia menunjukkan bahawa mikrosaluran memberi kesan ketara terhadap kadar pemindahan haba untuk kadar aliran yang terpilih. Keputusan berangka menggunakan perisian COMSOL 5.1 menunjukkan perbandingan yang baik dengan keputusan uji kaji. Pemerhatian kajian menunjukkan bahawa pekali pemindahan haba meningkat dengan nombor Reynolds manakala faktor geseran menurun dengan nombor Reynolds. Berdasarkan keputusan berangka dan uji kaji, korelasi empirik untuk faktor geseran dan nombor Nusselt dapat menyarankan anggaran yang bersesuaian dengan pemindahan haba dalam saluran mikro.

Kata kunci: Faktor geseran; nombor Nusselt; nombor Reynolds; pemindahan haba; saluran mikro

\section{INTRODUCTION}

The micro heat exchanger required to cool the electronic circuits by removing heat energy becomes an important area of developing technology-based on electronic circuits such as fuel processing and aerospace microminiature, micro heat pipe spreader, microelectronics, refrigerators, and biomedical. Therefore, to investigate the heat transfer and fluid flow in microchannels experimental investigation is equally important as a theoretical study. The first experiment to study the heat transfer and fluid flow characteristics for forced convective water flow through microchannels were conducted by Tuckerman and Pease 
(1981). The results of his study opened a wide research area for heat transfer in microdevices and electronics cooling. Choi et al. (1991) conducted the first experimental study for nitrogen gas in silica circular microtubes of length 24 to $52 \mathrm{~mm}$, and inside diameters $3,7,10,53$, and $81.2 \mu \mathrm{m}$ to study the heat transfer and pressure drop characteristic. The results show that the Nusselt number is the function of Reynolds Number in both turbulent and laminar flow.

Many researchers study the fluid flow and heat transfer characteristics in microchannels and minichannels by conducting experiments by varying the working fluids and cross-sectional areas (Ahmed et al. 2015; Anbumeenakshi et al. 2018; Dang et al. 2012; Duan et al. 2019; Khan, et al. 2011; Mehmood et al. 2014; Sharma 2014; Shaw et al. 2019; Tripathi et al. 2018) while a large number of analytical and numerical investigations (Ababaei et al. 2017; Abdollahi et al. 2018; Al-Zaidi et al. 2019; Jusoh et al. 2013; Nayak et al. 2018a, 2018b; Ranjith Kumar et al. 2019; Rehman et al. 2019; Uysal et al. 2016) were carried out due to some fabrication and experimental limitations to optimize the performance of microchannels. The heat transfer coefficient was investigated by Adams et al. $(1999,1998)$ for turbulent flow in circular channels of diameter 0.76 and $1.09 \mathrm{~mm}$ with water as working fluid inner diameters. The comparative results with microchannels show that the and compared the results Nusselt number for microchannels is comparatively less than the circular channel channels under study. Yu (1995) experimental results conducted on circular tubes of internal diameters 19.2, 52.1, and $102 \mu \mathrm{m}$ show that the heat transfer coefficient at low Reynolds number of circular tubes understudy and microtubes are very close to other but as Reynolds number increase the results of both starts diverting. An almost similar effect is noticed in Mala and Li (1999) experiment which was conducted on microtubes with an inner diameter from 50 to $254 \mu \mathrm{m}$. The results also show that in microchannels transition from laminar to turbulent flow is earlier as compared to circular channels.

The heat transfer coefficient was investigated by Adams et al. (1999, 1998) for turbulent flow in circular channels of diameter 0.76 and $1.09 \mathrm{~mm}$ with water as working fluid inner diameters. The comparative results with microchannels show that the and compared the results Nusselt number for microchannels is comparatively less than the circular channel channels under study. Yu (1995) experimental results conducted on circular tubes of internal diameters 19.2, 52.1, and $102 \mu \mathrm{m}$ show that the heat transfer coefficient at low Reynolds number of circular tubes understudy and microtubes are very close to other but as Reynolds number increase the results of both starts diverting. An almost similar effect is noticed in Mala and Li (1999) experiment which was conducted on microtubes with an inner diameter from 50 to $254 \mu \mathrm{m}$. The results also show that in microchannels transition from laminar to turbulent flow is earlier as compared to circular channels. Coleman and Garimella (2000) experimental investigate the effects of geometry, mass flux and quality on the phase-change flow mechanisms of two-phase flow mechanisms during condensation of refrigerant R134a in $4.91 \mathrm{~mm}$ round tube, and four round tubes with hydraulic diameters ranging from 1-4 $\mathrm{mm}$ for qualities $0<x<1$, and mass fluxes between 150 and $750 \mathrm{~kg} /$ $\mathrm{m}^{2} \mathrm{~s}$ to study. The results show that the intermittent flow regime becomes larger as the tube hydraulic diameter is decreased. Single-phase pressure drop for R-404A and $\mathrm{R}-22$, R-134A fluid flow in an aluminum tube having 2.13 $\mathrm{mm}$ of hydraulic diameter was investigated by Zhang and Webb (2001) and the results were able to predict the by using friction factor Blasius friction correlation within $\pm 10 \%$. Garimella et al. (2002) experimentally investigate rectangular, square, and round microchannel with R134a as working fluid during condensation of two-phase flow mechanisms. The result shows that tube shape or aspect ratio does not have a significant effect on flow regime transitions for similar hydraulic diameters. Garimella et al. (2005) and Liu and Garimella (2004) numerically and experimentally comparative investigate the pressure drop in a microchannel for hydraulic diameter and found that the conventional theory maybe uses to predict the flow behavior in a microchannel in a selected range of flow.

Matkovic et al. (2009) experimentally investigate $0.96 \mathrm{~mm}$ internal diameter circular minichannel of diameter $0.96 \mathrm{~mm}$ to find the local heat transfer coefficients during condensation of R134a and R32 and found that except for the lowest mass velocity, the test results do not show a significant discrepancy from the trends expected for macroscale tubes. Awad and Muzychka (2010) propose two-phase flow modeling to compute the frictional pressure gradient in microchannels and minichannels and finally suggested a simple rule for two-phase frictional pressure gradient in minichannels and microchannels. Analytical analysis of Entropy generations in the circular minichannel and microchannel was investigated by Sohel et al. (2013) using ethylene glycol (EG), $\mathrm{H}_{2} \mathrm{O}$, as the base fluids and alumina $\left(\mathrm{Al}_{2} \mathrm{O}_{3}\right)$, Copper $(\mathrm{Cu})$, as the nanoparticle in turbulent flow condition. The results of this study show that irrespective of nanofluid entropy generation decreases with the increase of volume fraction of the nanoparticles and decrease in the diameter of minichannel and microchannel. Shah (2016) experimentally verified the proposed correlations for heat transfer in horizontal single and multi mini/microchannels during condensation using halocarbon refrigerants, hydrocarbons, $\mathrm{CO}_{2}$ and water as working fluid in different shapes. Zhang et al. (2016) numerically investigate the pressure drop and heat transfer characteristics at saturation temperature $\mathrm{T}_{\text {sat }}=$ $320 \mathrm{~K}$ for R134a and R410A in flattened and horizontal 
round tubes. It was observed that with the increase of mass flux, vapor quality, and aspect ratio, pressure gradients, and local heat transfer coefficients also increases whereas the liquid film thickness decreases. Ghasemi et al. (2017) investigate experimentally and numerically using Finite Volume Method (FVM), the heat transfers and pressure drop in four circular minichannels by varying hydraulic diameter in three different values. The numerical and experimental comparative results show that experimental data are in good agreement with numerical results. The heat transfer characteristics and pressure drop in the heat sink are significantly affected by varying the channel diameter.

Gu et al. (2019) numerically investigate the horizontal channels having cross-section circular, triangular and square for Condensation characteristic of R1234ze(E). The results show under the same hydraulic diameter and same vapor quality, circular tubes have more void fraction than triangle and square tubes. Also, the transfer coefficients for the circular tube less as compared to that of the square and triangular tube. Pressure gradients are negligibly affected by the tube shape. In the circular tube and triangular tube, local film distribution is significantly affected by gravity as compared to the square tube. Overall, the pressure gradients or the heat transfer coefficients of the triangle or square tube were larger than that of the circular tube. Toninelli et al. (2019) investigated the condensation process for in the range of max flux of 65 and $200 \mathrm{~kg} / \mathrm{m}^{2} \mathrm{~s}$ in minichannels of the square and circular cross-section experimentally and numerically using threedimensional Volume of Fluid (VOF) simulations. The comparative study of condensation in square and circular minichannels helps to understand the mechanism of heat transfer in both cross-sections. Tiwari and Moharana (2018) numerically investigate the two-phase flow in wavy microchannels using the VOF under constant wall heat flux on one side of the substrate and insulated on the other side. The results show that in the presence of the bubble, the heat transfer coefficient slightly improves.

From the above literature survey, it is noticed that a lot of experimental and numerical studies have been done for predicting the heat transfer and pressure drop characteristics in circular microchannels under different conditions using different working fluids. The author observed that the comparative experimental and numerical investigation are necessary to predict the characteristic of fluid flow and heat transfer for forced flow in circular microchannels under uniform surface temperature conditions. The purpose of this study was the comparative analysis of numerical investigation using COMSOL software with experimental data obtained by conducting the number of experiments on circular microchannels having the hydraulic diameter of $279 \mu \mathrm{m}$ and $63 \mathrm{~mm}$ in length using water as working fluid on 5 channels which are equally spaced to each other under uniform surface temperature condition. The comparative analysis helps to predict the correlations for heat transfer, friction factor and pressure drop under imposed conditions.

\section{MATERIALS AND METHODS}

\section{EXPERIMENTAL PROCEDURE AND THEORETICAL ANALYSIS EXPERIMENTAL SETUP}

Figure 1 shows the schematic diagram of the experimental setup of the present study. The major components of the experimental setup are storage tank of 85-liter capacity, filter of $5 \mu \mathrm{m}$ particle (FI-ES-TCR-QC), GAF Series external pump having the flow rate in the range of 46 to $506 \mathrm{~mL} / \mathrm{min}$ with a maximum pressure difference of 17.2 bar, McMillan Flow S-111 Liquid Flow Meter having the range of 100 to $1000 \mathrm{~mL} / \mathrm{min}$, UIY6-D digital pressure meter (Model No.: UTOP), test section, heater, insulator, microchannels, data logger, measuring beaker, and weighing machine.

Water from the storage tank having the capacity of $85 \mathrm{~L}$ is pumped by $0.25 \mathrm{HP}$ pump through the flow meter and test section to the measuring beaker. The upper and bottom external surface of the test section is covered by electrical heating plates of $300 \mathrm{~W}$. The heater surface expose to the environment is covered by the insulation of glass fiber having the thickness of $5 \mathrm{~cm}$ to prevent heat transfer from the heater to the surrounding. Heaters are connected to the AC power supply via the power regulating unit to control the current and input voltage to the heaters. The current and voltage to the circuit of electrical heaters measured by beeslover 0-100V/A digital DC VA amp volt ammeter voltmeter.

The k-type thermocouples which having the accuracy of $0.5{ }^{\circ} \mathrm{C}$ attached with data logger (Elettronica Veneta heat transfer service unit Mod.TE6/EV) are used to measure the inlet and exit temperature of working fluid (water), oil temperature surrounded the microchannels at three different positions (upper, middle, and lower), heater temperature and insulation temperature. Rod type thermocouples were used to measure the inlet and exit temperature of working fluid as well as oil temperature in the oil bath inserted through the drilled hole of $2 \mathrm{~mm}$ diameter in the inlet and exit header of the test section and oil bath. Button type thermocouples were used to measure the temperature of the heater plate and insulator. All the thermocouples were pre-calibrated used in the current study under the different temperature ranges. A flowmeter (B011Q175PE) having an accuracy of $1 \%$ and flow rate in the range of 100-1000 Milliliters per minute was used to measure the flow rate of the working fluid by connecting it between the pump and the inlet section of the test specimen. Flowrate is checked by measuring the volume of working fluid in the collecting beaker with the help of a stopwatch. 


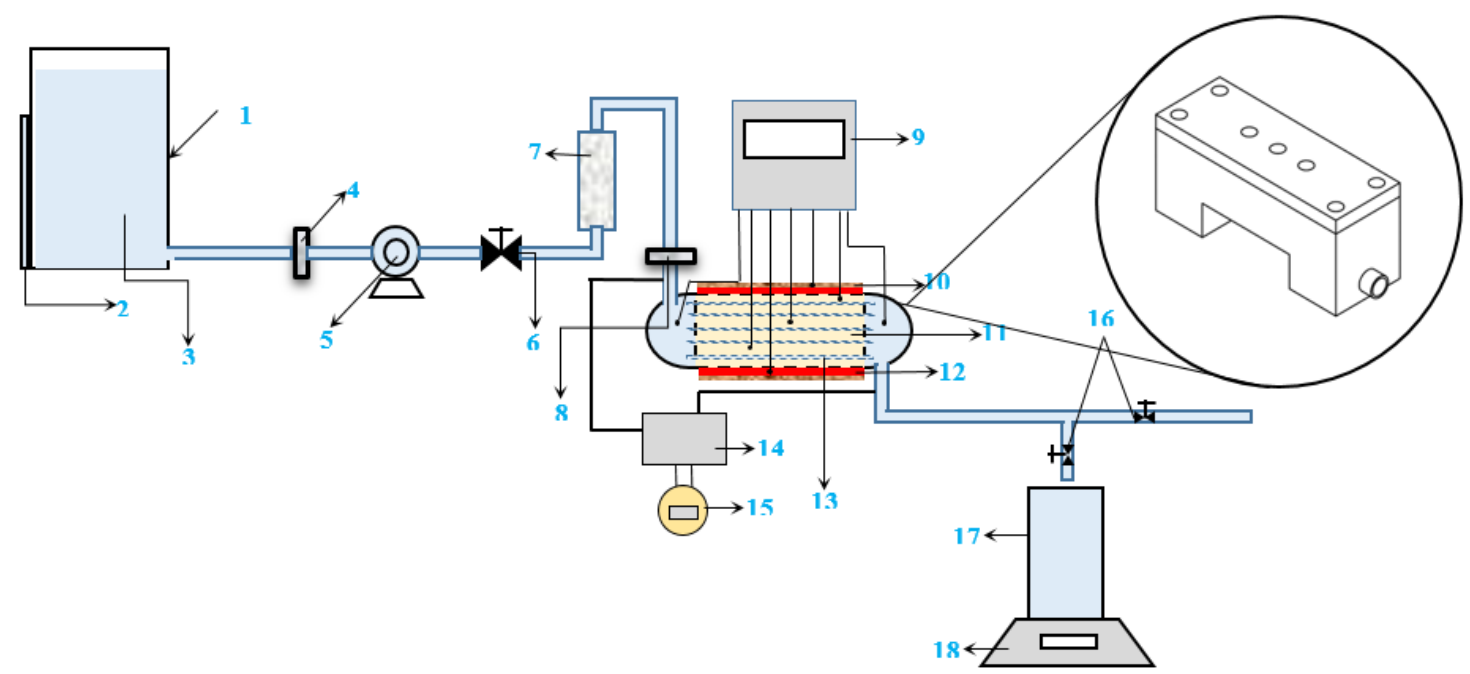

FIGURE 1. Experimental set-up: (1) storage tank, (2) measuring scale, (3) working fluid (water), (4) 8 - filter, (5) pump, (6) 16 - flow arte control regulator, (7) flow rate meter, (8) computer, (9) data logger, (10) insulator, (11) oil, (12) heater, (13) microchannels, (14) pressure transducer, (15) panel meter, (17) measuring beaker, and (18) weighing machine

To measure the pressure drop across the test section, a digital differential pressure gauge (UIY6-D Model No.: UTOP) has been used. The Digital differential pressure gauge having an accuracy of $0.1 \% \mathrm{FS}$.

Before taking experimental data while performing the experiments for a certain flow rate, flowrate regulator (point no. 6 in Figure 1) is used to adjust the flow rate across the channel. Once the required flow rate achieved, the current was supplied to the heater for heating the oil in the oil bath. When the temperature of oil in the oil bath reached the required value, the flow rate, the pressure drop across the test section, inlet and exit temperature of working fluid as well as the oil temperature of the test section were recorded under steady-state. After experimented with a particular flow rate, the system was shut down and repeat the experiments for the different flow rates of working fluid under the same boundary condition (same oil temperature in the oil bath) as the previous one.

\section{DATA REDUCTION}

The rate of heat gain by the working fluid from oil in the test section is given by Khoshvaght-Aliabadi et al. (2014)

$\dot{Q}=\dot{m}_{w} \cdot c_{p} \cdot\left(T_{w e}-T_{w i}\right)=\frac{\pi}{4} \mu \cdot d_{h} \cdot c_{p w} \cdot\left[\mathrm{R}_{\mathrm{e}} \cdot\left(T_{w e}-T_{w i}\right)\right]$

Average heat transfer coefficient is given by KhoshvaghtAliabadi et al. (2014):

$$
h_{\text {avg }}=\frac{\dot{Q}}{A_{s} \cdot\left(\left(T_{\text {oil }}\right)_{\text {avg }}-\left(T_{w}\right)_{\text {avg }}\right)}
$$

Average Nusselt Number is given by Ghaedamini et al. (2013) and Marshall et al. (2017):

$$
\bar{N} u=\frac{h_{\text {avg }} \cdot d_{h}}{k} \cdot \frac{\ln \left(\frac{T_{o i l}-T_{w i}}{T_{o i l}-T_{w e}}\right)}{\left(T_{o i l}-T_{w i}\right)-\left(T_{o i l}-T_{w e}\right)}
$$

Friction Factor is given by Heyhat et al. (2013):

$$
f=2 \cdot \frac{d_{h} \cdot \Delta p}{l \cdot \rho V_{a v g}^{2}}
$$

\section{MATHEMATICAL MODEL}

The geometry and boundary condition of the microchannel pipe model is shown in Figure 2. Heat is generated along the out surface and cooled by the water thath passes through the microchannel pipt at $\mathrm{T}_{1}=22^{\circ} \mathrm{C}$ with varying velocity and Reynolds number. The Conjugate heat model for the microchannel pipe is simulated via COMSOL 5.1. The simulation model set up is validated against the experimental work, where a hydraulic dimeter is $253 \mu \mathrm{m}$ and the length of the pipe is $63 \mathrm{~mm}$. The force convection kept laminar and the average error between the simulation model presented here and the experimental work is $4 \%$. 


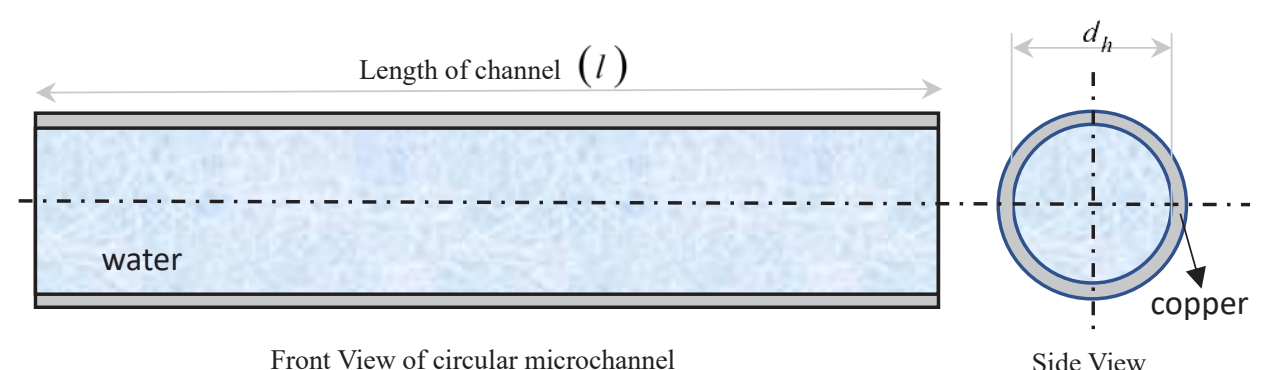

FIGURE 2. The geometry of the micro channel simulation model

In this study, the model fluid is flowing by forced convection through the channel. Before solving the full conjugate heat model, the fluid flows are checked to determine whether the flow is turbulent or laminar. For the water flowing in the channel this is determined by calculating the Reynolds number, $\mathrm{R}_{\mathrm{e}}$

$$
\mathrm{R}_{\mathrm{e}}=\frac{\rho_{w} V_{a v g} \cdot d_{h}}{\mu_{w}}
$$

For the water channel which is the forced convection laminar fluid domain. Therefore, the continuity equation, which in the Cartesian directions is given by

$$
\frac{\partial u}{\partial x}+\frac{\partial v}{\partial y}+\frac{\partial w}{\partial z}=0
$$

Momentum equation in X-direction

$$
\begin{aligned}
& \rho \frac{\partial u}{\partial t}+\rho\left[u \cdot \frac{\partial u}{\partial x}+v \cdot \frac{\partial u}{\partial y}+w \cdot \frac{\partial u}{\partial z}\right]=-\frac{\partial \rho}{\partial x}+ \\
& \mu\left[\frac{\partial^{2} u}{\partial x^{2}}+\frac{\partial^{2} u}{\partial y^{2}}+\frac{\partial^{2} u}{\partial z^{2}}\right]+\rho g_{x} \beta T
\end{aligned}
$$

Momentum equation in Y-direction

$$
\begin{aligned}
& \rho \frac{\partial v}{\partial t}+\rho\left[u \cdot \frac{\partial v}{\partial x}+v \cdot \frac{\partial v}{\partial y}+w \cdot \frac{\partial v}{\partial z}\right]=-\frac{\partial \rho}{\partial y}+ \\
& \mu\left[\frac{\partial^{2} v}{\partial x^{2}}+\frac{\partial^{2} v}{\partial y^{2}}+\frac{\partial^{2} v}{\partial z^{2}}\right]+\rho g_{y} \beta T
\end{aligned}
$$

Momentum equation in Z-direction

$$
\begin{gathered}
\rho \frac{\partial w}{\partial t}+\rho\left[u \cdot \frac{\partial w}{\partial x}+v \cdot \frac{\partial w}{\partial y}+w \cdot \frac{\partial w}{\partial z}\right]=-\frac{\partial \rho}{\partial z}+ \\
\mu\left[\frac{\partial^{2} w}{\partial x^{2}}+\frac{\partial^{2} w}{\partial y^{2}}+\frac{\partial^{2} w}{\partial z^{2}}\right]+\rho g_{z} \beta T
\end{gathered}
$$

Here, the flow is steady state so the variation due to time is not taking in account

$$
\frac{\partial u}{\partial t}=\frac{\partial v}{\partial t}=\frac{\partial w}{\partial t}=0
$$

The gravity acceleration effect is so small which can be neglected

$$
g_{x}=g_{y}=g_{z}=0
$$

Equations (6), (7) and (8) reduces to, Momentum equation in X-direction

$\rho\left[u \cdot \frac{\partial u}{\partial x}+v \cdot \frac{\partial u}{\partial y}+w \cdot \frac{\partial u}{\partial z}\right]=-\frac{\partial \rho}{\partial x}+\mu\left[\frac{\partial^{2} u}{\partial x^{2}}+\frac{\partial^{2} u}{\partial y^{2}}+\frac{\partial^{2} u}{\partial z^{2}}\right]$

Momentum equation in Y-direction

$\rho\left[u \cdot \frac{\partial v}{\partial x}+v \cdot \frac{\partial v}{\partial y}+w \cdot \frac{\partial v}{\partial z}\right]=-\frac{\partial \rho}{\partial y}+\mu\left[\frac{\partial^{2} v}{\partial x^{2}}+\frac{\partial^{2} v}{\partial y^{2}}+\frac{\partial^{2} v}{\partial z^{2}}\right]$

Momentum equation in Z-direction

$\rho\left[u \cdot \frac{\partial w}{\partial x}+v \cdot \frac{\partial w}{\partial y}+w \cdot \frac{\partial w}{\partial z}\right]=-\frac{\partial \rho}{\partial z}+\mu\left[\frac{\partial^{2} w}{\partial x^{2}}+\frac{\partial^{2} w}{\partial y^{2}}+\frac{\partial^{2} w}{\partial z^{2}}\right]$

The energy equation

$\rho c_{p}\left[\frac{\partial T}{\partial t}+u \cdot \frac{\partial T}{\partial x}+v \cdot \frac{\partial T}{\partial y}+w \cdot \frac{\partial T}{\partial z}\right]=k_{l}\left[\frac{\partial^{2} T}{\partial x^{2}}+\frac{\partial^{2} T}{\partial y^{2}}+\frac{\partial^{2} T}{\partial z^{2}}\right]$

In the solid domain which is the pipe, only the energy equation is required

$$
0=k_{s}\left[\frac{\partial^{2} T}{\partial x^{2}}+\frac{\partial^{2} T}{\partial y^{2}}+\frac{\partial^{2} T}{\partial z^{2}}\right]
$$

where, the $k_{s}$ is the thermal conductivity for the solid and $k_{l}$ is the thermal conductivity for the liquid. 
The boundary conditions can be written as follow: Under no slip on all solid walls

$$
u . n=0
$$

There are conjugate heat transfer interfaces which are temperature interfaces between the microchannel and water

$$
T_{M C}=T_{w}
$$

And heat is continuous, so that the heat lost from microchannel surface is the same as the heat gained by the water:

$$
-n \cdot\left(-k_{c u} \nabla T_{M C}\right)=-n \cdot\left(-k_{w} \nabla T_{w}\right)
$$

The outlet of the water in the microchannel test section has pressure defined

$$
P_{\text {out }}=0
$$

The outlet boundary for force convection heat transfer domain. The equation that implemented for outflow heat transfer

$$
-n \cdot\left(-k_{w} \nabla T_{w}\right)=0
$$

\section{RESULTS AND DISCUSSION}

This study is the numerical and experimental investigation of fluid flow and heat transfer in circular microchannels having a hydraulic diameter of $253 \mu \mathrm{m}$ and $63 \mathrm{~mm}$ in length. In experiment water at $22^{\circ} \mathrm{C}$ passes through the test section containing five channels. All five channels of the test section are submerged in oil and the oil temperature kept at $75{ }^{\circ} \mathrm{C}$ by heating it through the heater. When the water passes through these channels gets heated by the surrounding oil temperature. The inlet and exit temperature measured with the help of a data logger and digital differential manometer used to measure the pressure difference at the inlet and exit of the test section. Using (1) heat gain by the working fluid (water) flowing through the microchannels from the oil is calculated by (1). The flow rate through the test section ranges from Reynolds number 900 to 1700 . Nusselt number and Friction factor are calculated using (3) and (4). Figure 3 shows the variation of friction factor along the length of the channel for different values of the Reynolds number. It is noted that for the particular flow rate (Reynolds number), the friction factor decreases with channel length and for a particular position of the channel, friction factor increases with flow rate (Reynolds number). The physical reason for decrease in friction factor along the length of the channel at particular Reynolds number is that when the fluid enters the channel inertial forces are on the peak and inertial forces decreases as the fluid flow comes in progress. Figure 4 shows the variation of local Nusselt number along the length of the channel for different flow rate. It is observed that for the particular flow rate or Reynolds number, the local Nusselt number decreases almost parabolically with channel length. The Nusselt number directly proportional to the heat transfer coefficient and the heat transfer coefficient is inversely proportional to the surface are of the channel which is the function of channel diameter as well as length of channel. In this way, Nusselt number is inversely proportional to the length of the channel. And this is the reason that Nusselt number decreases along the length of the channel.

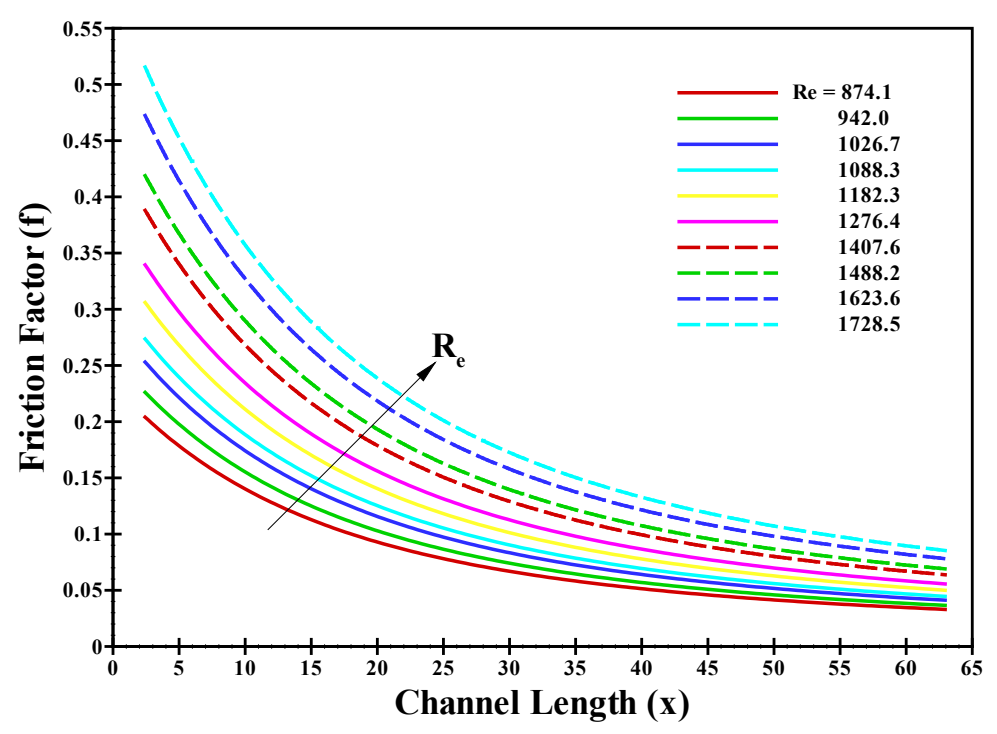

FIGURE 3. Friction factor Vs Reynolds number 


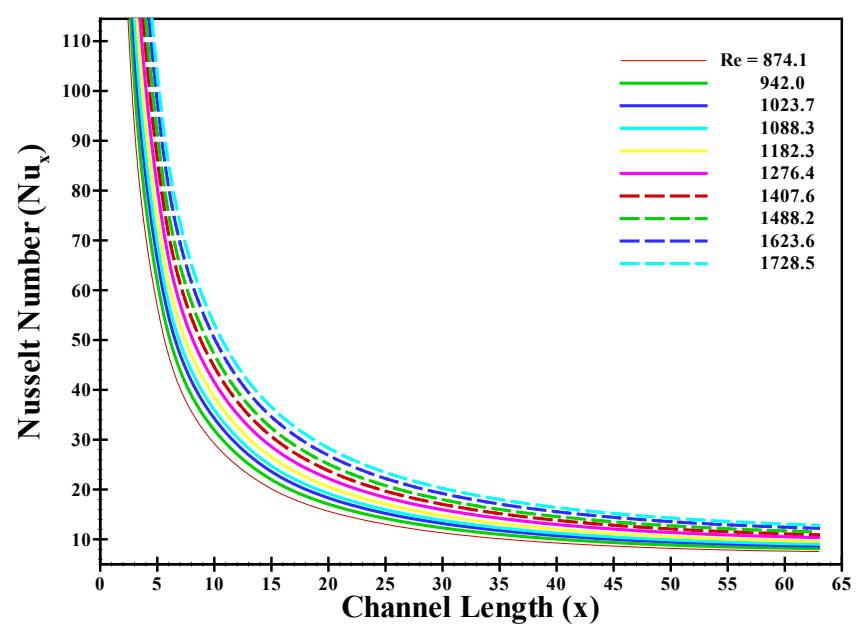

FIGURE 4. Friction factor Vs Reynolds number

Experimental friction factor and Nusselt number is plotted against Reynolds number in Figures 5 and 6, respectively. In Figure 5, it is noted that friction factor decreases with increase of Reynolds number along the channels. As the flow rate through the channels increases, velocity of flow also increases proportionally because velocity is directly proportional to flow rate. In (4), friction factor depends on hydraulic diameter of the channel, length of channel, density of fluid flow, inlet- exit pressure difference and velocity of flow. For the particular channel and for the particular fluid, the hydraulic diameter, length and density of fluid is constant. In that case the friction factor decreases with velocity of flow or Reynolds number. Also, with increase of velocity, the pressure difference between the inlet and exit increases but the rate of increase of pressure difference between the inlet and exit section of the channel is much less as compared to the rate of increase of velocity of flow. The experimental results of friction factor show good agreement with the numerical results. Figure 4 shows that experimental values as well as Khan et al. (2011) results with in the $\pm 4 \%$ of numerical results. The empirical equation for friction factor as a function of Reynolds number is given by $f-1.1267 . R_{e}^{-0.605}$. This means that by using this relation friction factor can be predicated under the same boundary conditions and the value of predicated friction factor having the maximum error of $\pm 4 \%$. Figure 6 shows the numerical, experimental and Khan et al. (2011) Nusselt number verse Reynolds number. It is noted that Nusselt number increases with Reynolds number. Equation (3) shows that Nusselt number is the function of average heat transfer coefficient, hydraulic diameter and thermal conductivity of working fluid. For particular channels and working fluid, hydraulic diameter and thermal conductivity of working fluid remains constant, therefore Nusselt number is directly proportional to average heat transfer coefficient.

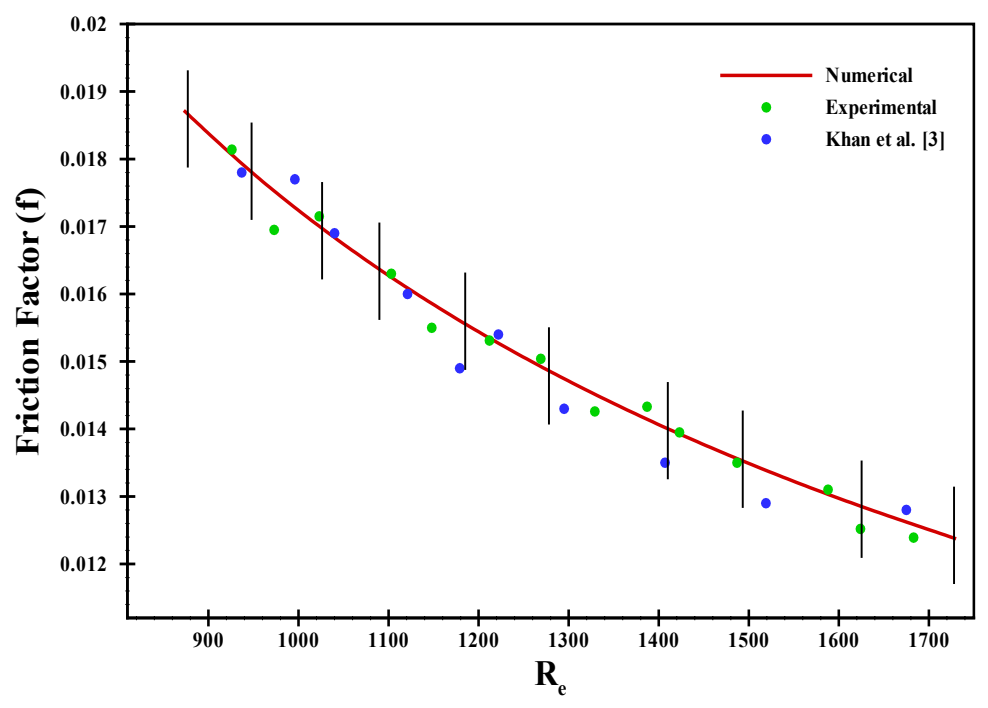

FIGURE 5. Friction factor Vs Reynolds number 


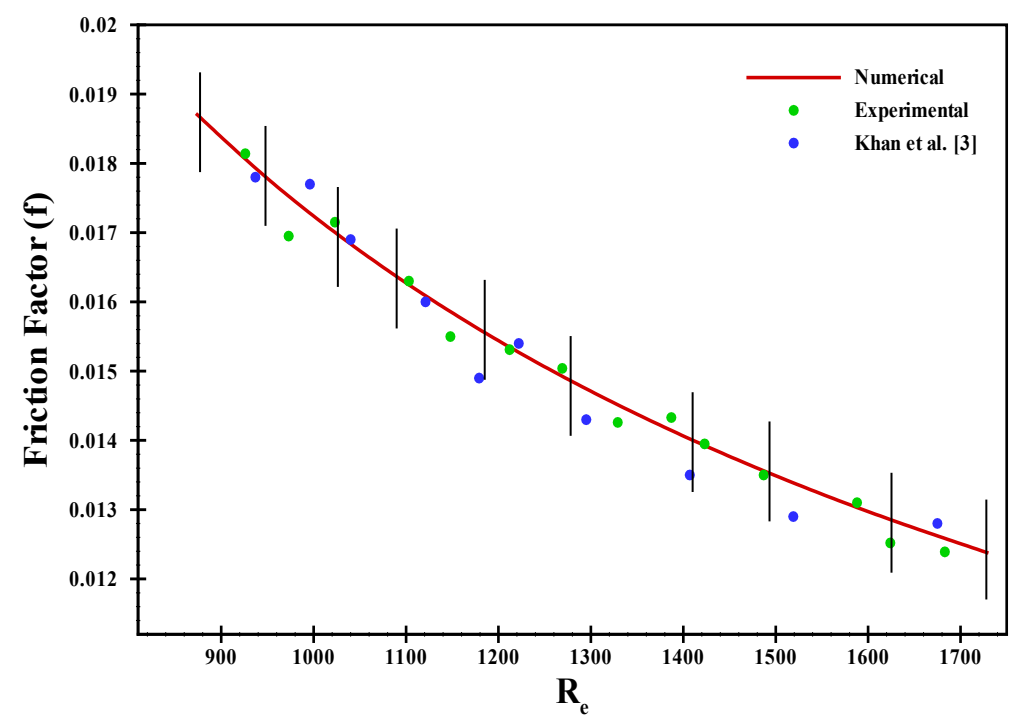

FIGURE 6. Nusselt number Vs Reynolds number

Equation (2) indicated that average heat transfer coefficient is directly proportional to the rate of heat transfer from oil to working fluid and inversely proportional to difference between the oil temperature and average of inlet and exit temperature of working fluid. The rate of heat transfers from oil to working fluid is proportional to Reynolds number and difference of inlet-exit temperature of working fluid. Experimentally, it is noted that temperature difference between inletexit section of working fluid decreases with flow rate or Reynolds number. But the rate of increase of Reynolds number is much more than temperature difference of working fluid between inlet-exit section. Because of this heat transfer $(\dot{Q})$ increases with Reynolds number $\left(R_{e}\right)$ and proportionally average heat transfer coefficient (h) and Nusselt number $(\mathrm{Nu})$ increase. It is also observed that the experimental results of present study and Khan et al. (2011) results have good agreement with numerical results. From numerical data, the suggested correlation for Nusselt number as function of Reynolds number is given by $N u=\left(500 . \mathrm{R}_{\mathrm{e}} / 3\right)+4.5107$. The results obtained by this empirical equation are with the error of $\pm 4 \%$ with the actual results.

\section{CONCLUSION}

Fluid flow and heat transfer in circular microchannels having a hydraulic diameter of $253 \mu \mathrm{m}$ and $63 \mathrm{~mm}$ in length are numerically and experimentally investigated in the present study. Under constant wall temperature, pressure, and temperature were recorded at the inlet and exit position of the test section in the range of 900 to 1700 Reynolds number. The friction factor, average heat transfer coefficient, and Nusselt number are evaluated by well know equations using experimental data. Numerical and experimental friction factor, as well as Nusselt number, were plotted versus Reynolds number. It is observed that the experimental friction factor and Nusselt number matched reasonably well with the numerical results. Correlation for friction factor and Nusselt number were proposed in terms of Reynolds number based on experimental and numerical results. It is also noted that both experimental and numerical results of the present study matched with already published results. The behavior of fluid flow and heat transfer can be predicated by proposed correlations under the same boundary conditions.

From the present study, it is clear that the heat transfer coefficient, Nusselt number and friction factor depends on the number of factors like the diameter of channels, length of the channel, material of channel, fluid envelop the channels as well as properties of the working fluid. The present study could be extended by varying these parameters and compared the obtained results with the results obtained in the present study.

\section{ACKNOWLEDGEMENTS}

The author would like to thank Deanship of Scientific Research at Majmaah University for supporting this work under the Project Number No. R-1441-123. 


\section{REFERENCES}

Ababaei, A., Arani, A.A. \& Aghaei, A. 2017. Numerical investigation of forced convection of nanofluid flow in microchannels: Effect of adding micromixer. Journal of Applied Fluid Mechanics 10(6): 1759-1772.

Abdollahi, A., Mohammed, H.A., Vanaki, S.M. \& Sharma, R.N. 2018. Numerical investigation of fluid flow and heat transfer of nanofluids in microchannel with longitudinal fins. Ain Shams Engineering Journal 9(4): 3411-3418.

Adams, T.M., Dowling, M.F., Abdel-Khalik, S.I. \& Jeter, S.M. 1999. Applicability of traditional turbulent single-phase forced convection correlations to non-circular microchannels. International Journal of Heat and Mass Transfer 42: 44114415.

Adams, T.M., Abdel-Khalik, S.I., Jeter, S.M. \& Qureshi, Z.H. 1998. An experimental investigation of single-phase forced convection in microchannels. International Journal of Heat and Mass Transfer 41(6-7): 851-857.

Ahmed, M.A., Yusoff, M.Z., Ng, K.C. \& Shuaib, N.H. 2015. Numerical and experimental investigations on the heat transfer enhancement in corrugated channels using $\mathrm{SiO}_{2}-$ water nanofluid. Case Studies in Thermal Engineering 6: 77-92.

Al-Zaidi, A.H., Mahmoud, M.M. \& Karayiannis, T.G. 2019. Flow boiling of HFE-7100 in microchannels: Experimental study and comparison with correlations. International Journal of Heat and Mass Transfer 140: 100-128.

Anbumeenakshi, C., Sunndhar, P.M., Sundaram, P.K. \& Thansekhar, M.R. 2018. Experimental investigation of heat transfer study in rectangle type straight and oblique finned microchannel heat sink with nanofluids. International Research Journal of Engineering and Technology 5(12): 621-634.

Awad, M.M. \& Muzychka, Y.S. 2010. Two-phase flow modeling in microchannels and minichannels. Heat Transfer Engineering 31(13): 1023-1033.

Choi, S.B., Barron, R.F. \& Warrington, R.O. 1991. Fluid flow and heat transfer in microtubes. American Society of Mechanical Engineers, Dynamic Systems and Control Division. United Kingdom: DSC Publications Ltd.

Coleman, J.W. \& Garimella, S. 2000. Two-phase flow regime transitions in microchannel tubes: The effect of hydraulic diameter. Proc. ASME Heat Transfer Division-2000 HTD 366-4: 71-83.

Dang, T., Tran, N. \& Teng, J.T. 2012. Numerical and experimental investigations on heat transfer phenomena of an aluminium microchannel heat sink. Applied Mechanics and Materials 145: 129-133.

Duan, Z., Ma, H., He, B., Su, L. \& Zhang, X. 2019. Pressure drop of microchannel plate fin heat sinks. Micromachines 10(2): 2-18.

Garimella, S., Agarwal, A. \& Killion, J.D. 2005. Condensation pressure drop in circular microchannels. Heat Transfer Engineering 26(3): 28-35.

Garimella, S., Killion, J.D. \& Coleman, J.W. 2002. An experimentally validated model for two-phase pressure drop in the intermittent flow regime for circular microchannels. $J$. Fluids Eng. 124(1): 205-214.
Ghaedamini, H., Lee, P.S. \& Teo, C.J. 2013. Developing forced convection in converging-diverging microchannels. International Journal of Heat and Mass Transfer 65: 491499.

Ghasemi, S.E., Ranjbar, A.A. \& Hosseini, M.J. 2017. Experimental and numerical investigation of circular minichannel heat sinks with various hydraulic diameter for electronic cooling application. Microelectronics Reliability 73: 97-105.

Gu, X., Wen, J., Zhang, X., Wang, C. \& Wang, S. 2019. Effect of tube shape on the condensation patterns of R1234ze(E) in horizontal mini-channels. International Journal of Heat and Mass Transfer 131: 121-139.

Heyhat, M.M., Kowsary, F., Rashidi, A.M., Momenpour, M.H. \& Amrollahi, A. 2013. Experimental investigation of laminar convective heat transfer and pressure drop of water-based $\mathrm{Al}_{2} \mathrm{O}_{3}$ nanofluids in fully developed flow regime. Experimental Thermal and Fluid Science 44: 483-489.

Jusoh, M.F., Zawawi, M.A.M., Man, H.C. \& Kamaruddin, S. 2013. Performance of shallow tube well on groundwater irrigation in tropical lowland rice cultivation area. Sains Malaysiana 48(2): 1101-1108.

Khan, M.N., Islam, M. \& Hasan, M.M. 2011. Experimental approach to study friction factor and temperature profiles of fluid flow in circular microchannels. Journal of Mechanical Engineering Research 3(6): 209-217.

Khoshvaght-Aliabadi, M., Hormozi, F. \& Zamzamian, A. 2014. Experimental analysis of thermal-hydraulic performance of copper-water nanofluid flow in different plate-fin channels. Experimental Thermal and Fluid Science 52: 248-258.

Liu, D. \& Garimella, S.V. 2004. Investigation of liquid flow in microchannels. Journal of Thermophysics and Heat Transfer 18(1): 65-72.

Mala, G.M. \& Li, D. 1999. Flow characteristics of water in microtubes. International Journal of Heat and Fluid Flow 20(2): 142-148.

Marshall, S.D., Balasubramaniam, L., Arayanarakool, R., Li, B., Lee, P.S. \& Chen, P.C. 2017. Case studies in thermal engineering methods and techniques of improving experimental testing for micro fluidic heat sinks. Case Studies in Thermal Engineering 10: 227-233.

Matkovic, M., Cavallini, A., Del Col, D. \& Rossetto, L. 2009. Experimental study on condensation heat transfer inside a single circular minichannel. International Journal of Heat and Mass Transfer 52(9-10): 2311-2323.

Mehmood, O.U., Mustapha, N., Shafie, S. \& Hayat, T. 2014. Partial slip effect on heat and mass transfer of MHD peristaltic transport in a porous medium. Sains Malaysiana 43(7): 1109-1118.

Nayak, M.K., Shaw, S., Makinde, O.D. \& Chamkha, A.J. 2018a. Effects of homogenous-heterogeneous reactions on radiative $\mathrm{NACl}-\mathrm{CNP}$ nanofluid flow past a convectively heated vertical Riga plate. Journal of Nanofluids 7(4): 657-667.

Nayak, M.K., Shaw, S., Pandey, V.S. \& Chamkha, A.J. 2018 b. Combined effects of slip and convective boundary condition on MHD 3D stretched flow of nanofluid through porous media inspired by non-linear thermal radiation. Indian Journal of Physics 92: 1017-1028. 
Ranjith Kumar, V., Balasubramanian, K., Kiran Kumar, K., Tiwari, N. \& Bhatia, K. 2019. Numerical investigation of fluid flow and heat transfer characteristics in novel circular wavy microchannel. Proceedings of the Institution of Mechanical Engineers, Part E: Journal of Process Mechanical Engineering 233(5): 954-966.

Rehman, D., Morini, G.L. \& Hong, C. 2019. A comparison of data reduction methods for average friction factor calculation of adiabatic gas flows in microchannels. Micromachines 10(2): 2-18.

Shah, M.M. 2016. A correlation for heat transfer during condensation in horizontal $\mathrm{mini} / \mathrm{micro}$ channels. International Journal of Refrigeration Volume 64: 187-202.

Sharma, P. 2014. Forced convective heat transfer characteristics of water through a minichannel at higher Reynolds number. International Journal for Scientific Research and Development 1(11): 2533-2536.

Shaw, S., Motsa, S.S. \& Sibanda, P. 2019. Nanofluid flow over three different geometries under viscous dissipation and thermal radiation using the local linearization method. Heat Transfer - Asian Research 48: 1-17.

Sohel, M.R., Saidur, R., Hassan, N.H., Elias, M.M., Khaleduzzaman, S.S. \& Mahbubul, I.M. 2013. Analysis of entropy generation using nanofluid flow through the circular microchannel and minichannel heat sink. International Communications in Heat and Mass Transfer 46: 85-91.

Tiwari, N. \& Moharana, M.K. 2018. Two-phase flow conjugate heat transfer in wavy microchannel. $A S M E$ 2018 16th International Conference on Nanochannels, Microchannels, and Minichannels.

Toninelli, P., Bortolin, S., Azzolin, M. \& Del Col, D. 2019. Effects of geometry and fluid properties during condensation in minichannels: Experiments and simulations. Heat and Mass Transfer 55(1): 41-57.
Tripathi, D., Jhorar, R., Bég, O.A. \& Shaw, S. 2018. Electroosmosis modulated peristaltic biorheological flow through an asymmetric microchannel: Mathematical model. Meccanica 53: 2079-2090.

Tuckerman, D.B. \& Pease, R.F.W. 1981. High-performance heat sinking for VLSI. IEEE Electron Device Letters 2(5): 126-129.

Uysal, C., Arslan, K. \& Kurt, H. 2016. A numerical analysis of fluid flow and heat transfer characteristics of $\mathrm{ZnO}$-ethylene glycol nanofluid in rectangular microchannels. Strojniški vestnik-Journal of Mechanical Engineering 62(10): 603-613.

Yu, D. 1995. An experimental and theoretical investigation of fluid flow and heat transfer in microtubes. ASME/JSME Thermal Engineering Conference 7(1): 11-16.

Zhang, J., Li, W. \& Sherif, S.A. 2016. A numerical study of condensation heat transfer and pressure drop in horizontal round and flattened minichannels. International Journal of Thermal Sciences 106: 80-93.

Zhang, M. \& Webb, R.L. 2001. Correlation of two-phase friction for refrigerants in small-diameter tubes. Experimental Thermal and Fluid Science 25(3-4): 131-139.

Department of Mechanical and Industrial Engineering College of Engineering

Majmaah University

Al-Majmaah, 11952

Saudi Arabia

*Corresponding author; email: a.almaneeea@mu.edu.sa

Received: 28 October 2019

Accepted: 1 May 2020 